\section{Three White-bracted Cultivars of Cornus florida Resistant to Powdery Mildew}

\author{
M.T. Windham ${ }^{1}$, W.T. Witte ${ }^{2}$, and R.N. Trigiano ${ }^{1}$ \\ Tennessee Agricultural Experiment Station, Knoxville, TN 37996-4500
}

Additional index words. disease resistance, flowering dogwood, Microsphaera pulchra

Flowering dogwood (Cornus florida L.) is a popular ornamental tree that has been a profitable product for the nursery industry for many years. Since 1994, powdery mildew epidemics have impeded flowering dogwood production throughout much of the eastern United States (Hagan et al., 1998; Ranney et al., 1994; Windham and Witte, 1998). Symptoms associated with this disease are shriveled, desiccated leaves that contain increased red pigment, stunting of shoots, and lack of tree growth in height and caliper. Signs of the pathogen include white, powdery mycelium on adaxial leaf surfaces that form during hot, humid weather, and small tan to black cleistothecia on abaxial leaf surfaces that form during the fall. Nearly $100 \%$ of the foliage of seedlings or liners may be affected, which can result in twig or plant death. Older trees that have been established for several years usually do not die, but grow poorly and have reduced number of inflorescences the following spring.

Two powdery mildew species have been associated with flowering dogwood in North America, Microsphaera pulchra Cooke and Peck(Farretal., 1989; Ranney et al., 1994) and Phyllactinia guttata (Wallr.:Fr.) Lev. (Burrill and Earle, 1887; Farr et al., 1989; McRitchie, 1994). Klein et al. (1998) attributed the epidemics that have ravaged dogwoods in nursery fields and landscape settings to M. pulchra.

Although more than 100 cultivars of flowering dogwood are available (Santamour and McArdle, 1985), only one pink-bracted cultivar, 'Cherokee Brave', has been consistently resistant to powdery mildew (Hagan et al., 1998; Windham, 1996). Windham and Witte (1998) found that resistance to powdery mildew occurred in dogwood populations with a frequency of $\approx 0.001$. They cautioned that not all powdery mildew-free dogwoods in field settings were resistant and that trees could vary in their level of resistance.

Received for publication 31 July 2001. Accepted for publication 12 Dec. 2002. This research was supported by the Tennessee Agricultural Experiment Station, a grant from the Horticultural Research Institute, and gifts from Commercial Nursery, Decherd, Tenn.; Tennessee Valley Nursery, Winchester, Tenn.; and Shadow Nursery, Winchester, Tenn.

${ }^{1}$ Dept. of Entomology and Plant Pathology, The Univ. of Tennessee, Knoxville, TN 37996-4500. Reprint requests should be addressed to R.N.T. or e-mail: rtrigian@utk.edu

${ }^{2} 7916$ Martin Mill Pike, Knoxville, TN 37920
The objective of this project was to evaluate 20 lines of powdery mildew resistant flowering dogwoods for superior horticultural traits, including potential for early flowering periodicity, bract size, color, degree of overlap, cleft color, and stiffness of bracts. Six lines were (C) 'Kay's Appalachian Mist. selected for early flowering periodicity. From these six, bract size and bract characteristics were used to select three lines for development and release.

\section{Origin}

The trees were discovered as seedlings growing in fields of dogwood seedlings that were abandoned in response to severe outbreaks of powdery mildew at Commercial Nursery, Decherd, Tenn., in 1994 or 1995. Seed planted in these fields were obtained by professional seed collectors who had gathered seed in Tennessee, Georgia, and Alabama. Because seed were bulked, the geographic origins of the seed for our powdery mildew resistant lines were not determined. Methodology for selection of seedlings from these fields is described in Windham and Witte (1998).
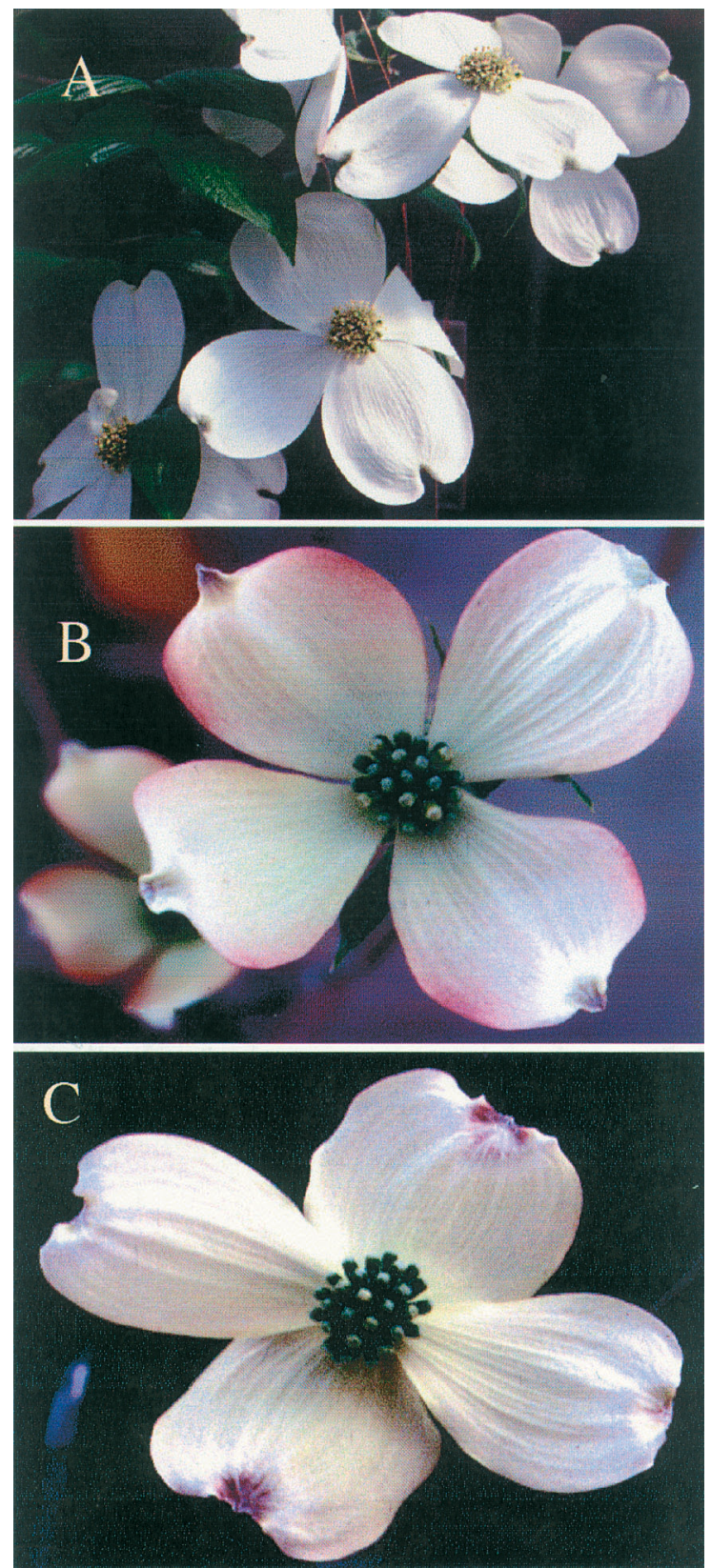

Fig. 1. Bracts and inflorescence of (A) 'Jean's Appalachian Snow', (B) 'Karen's Appalachian Blush', and 


\section{Description}

'Jean's Appalachian Snow' (Fig.1A) is a white-bracted, flowering ${ }^{\mathrm{TM}}$ dogwood having bract clefts with 145C, yellow-green coloration (Royal Horticulture Society, 1990; all subsequent references to color numbers are from the same source). Bract length and width average 5.8 and $4.8 \mathrm{~cm}$, respectively, of the largest bract pair $(n=46$, typically the inner pair of bracts that immediately subtends the inflorescence receptacle). Bracts are longitudinally striated, stiff, and overlap. Petals are $150 \mathrm{~B}$, yellow-green, and there are an average of 23 flowers per inflorescence $(n=23)$. Leaf color is $144 \mathrm{~A}$, yellow-green, and bark color is 202C, gray. Fall foliage is reddish-green, but was not classified using color charts.

'Karen's Appalachian Blush' (Fig. 1B) is a white-bracted, flowering dogwood with 73B, light pink, bract margins and a 60A, red-purple colored cleft. Bract length and width average 5.3 and $4.3 \mathrm{~cm}$, respectively, of the largest pair ( $\mathrm{n}=50$, typically the inner pair of bracts that immediately subtends the inflorescence receptacle). Bracts are thin, floppy, longitudinally striated, and do not overlap. Petals are 114B, yellow-green, and there are an average of 21 flowers per inflorescence $(n=37)$. Leaf color is $146 \mathrm{C}$, yellow-green, and bark color is $202 \mathrm{C}$, gray. Fall foliage is a vivid red, but was not classified using color charts.

'Kay's Appalachian Mist' (Fig. 1C) is a white-bracted dogwood having 60A, redpurple clefts. Bract length and width average 5.3 and $4.1 \mathrm{~cm}$, respectively, of the largest bract pair $(n=44$, typically the inner pair of bracts that immediately subtends the inflorescence receptacle). Bracts are stiff and overlap the outer bracts, which tend to be blocky in conformation. Petals are 144B, yellow-green, and there are an average of 22 flowers per inflorescence $(n=22)$. Leaf color is $144 B$, yellow-green, and bark color is 202C, gray. Fall foliage color is a vivid red, but was not classified using color charts.

\section{Disease resistance}

'Jean's Appalachian Snow' and 'Karen's Appalachian Blush' have demonstrated resistance to powdery mildew for each of 5 years and 'Kay's Appalachian Mist' for 6 years. These trees were three of 84 seedlings selected from 20,922 assayed seedlings as being free of powdery mildew in the field. In greenhouse trials in 1996 for 'Jean's Appalachian Snow' and 'Karen's Appalachian Blush', and 1995 and 1996 for 'Kay's Appalachian Mist', all were rated as disease-free with a disease severity score of 0.0 , whereas control trees averaged a disease rank of 5.0 ( Table 1). In 1997-99, the three trees were evaluated for powdery mildew resistance, and resistance levels were compared with the resistance levels in the commercially available 'Cherokee Brave', a resistant red-bracted cultivar, and 'Cherokee Sunset', a susceptible white-bracted cultivar with variegated leaves. The selected trees demonstrated less disease than the commercially available cultivars (Table 1).
Table 1. Comparison of resistance of Cornusflorida 'Jean's Appalachian Snow', 'Karen's Appalachian Blush', 'Kay's Appalachian Mist', 'Cherokee Brave', 'Cherokee Sunset', and C. florida flowering dogwood seedlings to powdery mildew.

\begin{tabular}{lccccc}
\hline & \multicolumn{5}{c}{ Mean mildew score } \\
\cline { 2 - 6 } Cultivars & 1995 & 1996 & 1997 & 1998 & 1999 \\
\hline Jean's Appalachian Snow & 0.0 & 0.0 & 0.0 & 0.0 & 1.0 \\
Karen's Appalachian Blush & --- y & 0.0 & 0.0 & 0.0 & 1.0 \\
Kay's Appalachian Mist' & --- & 0.0 & 0.0 & 0.0 & 1.0 \\
Cherokee Brave & --- & --- & 2.3 & 1.7 & 2.8 \\
Cherokee Sunset & --- & --- & 4.6 & 4.8 & 5.0 \\
C. florida seedlings & 5.0 & 5.0 & --- & --- & --- \\
\hline
\end{tabular}

Powdery mildew scores are based on the following scale: $0=$ healthy, $1=\leq 2 \%$ of foliage with signs of symptoms of powdery mildew; $2=\leq 10 \%$ of foliage with signs or symptoms of powdery mildew; $3=\leq 25 \%$ of foliage with signs or symptoms of powdery mildew; $4=\leq 50 \%$ of foliage with signs or symptoms of powdery mildew; $5=>50 \%$ of foliage with signs or symptoms of powdery mildew.

yot determined.

Table 2. Similarity matrix based on Jaccard coefficient among eight cultivars of flowering dogwood.

\begin{tabular}{lcccccccr}
\hline Cultivar & 1 & 2 & 3 & 4 & 5 & 6 & 7 & 8 \\
\hline Appalachian Spring (1) & 1.00 & & & & & & & \\
Kay's Appalachian Mist (2) & 0.80 & 1.00 & & & & & & \\
Jean's Appalachian Snow (3) & 0.76 & 0.76 & 1.00 & & & & & \\
Cloud 9 (4) & 0.75 & 0.70 & 0.77 & 1.00 & & & & \\
Karen's Appalachian Blush (5) & 0.79 & 0.79 & 0.78 & 0.75 & 1.00 & & & \\
Cherokee Princess (6) & 0.78 & 0.84 & 0.82 & 0.78 & 0.85 & 1.00 & & \\
Springtime (7) & 0.78 & 0.82 & 0.76 & 0.77 & 0.82 & 0.86 & 1.00 & \\
Cherokee Brave (8) & 0.79 & 0.77 & 0.73 & 0.72 & 0.78 & 0.79 & 0.82 & 1.00 \\
\hline
\end{tabular}

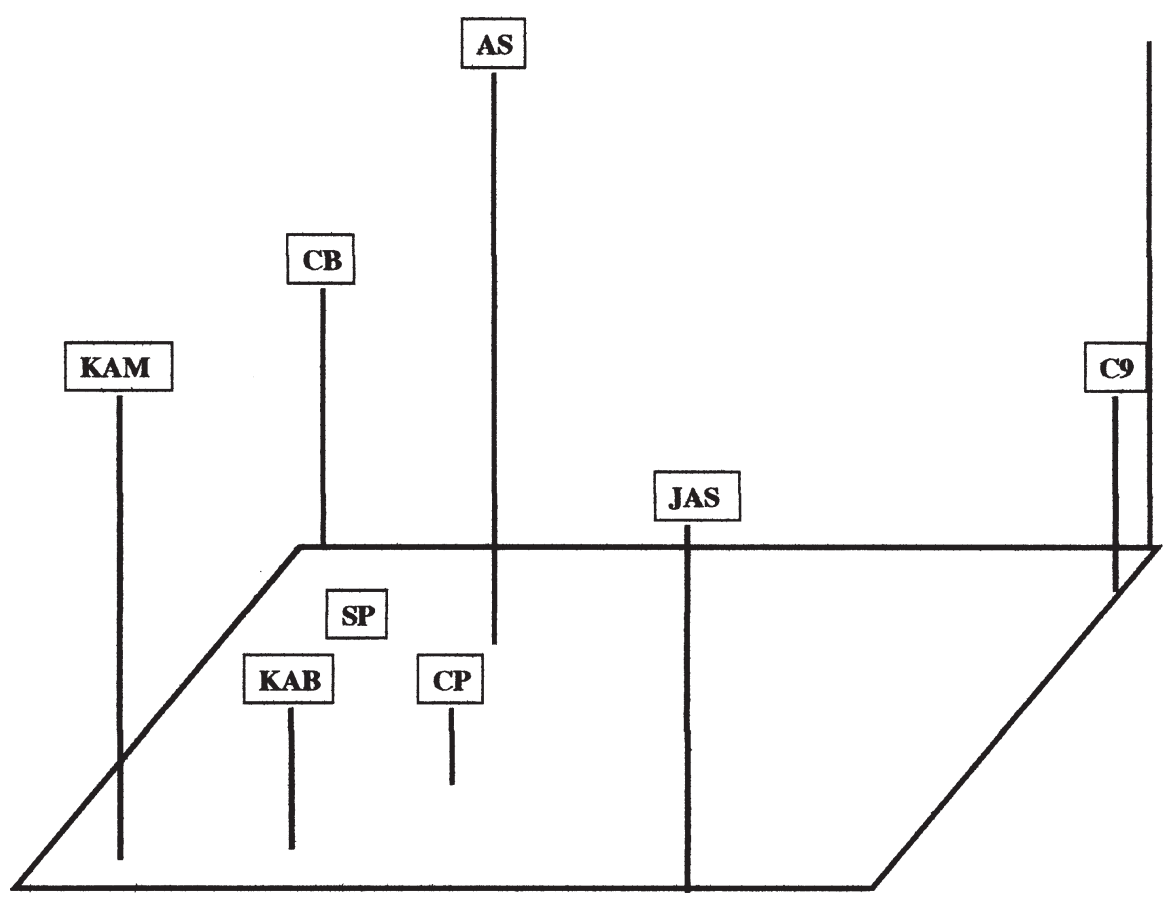

Fig. 2. Principal Coordinate Analysis of DNA amplification fingerprinting (DAF) data for the following eight cultivars of flowering dogwood: 'Appalachian Spring' (AS), 'Kay's Appalachian Mist' (KAM), 'Jean's Appalachian Snow' (JAS), 'Cloud 9' (C9), 'Karen's Appalachian Blush' (KAB), 'Cherokee Princess' (CP), 'Springtime' (SP), and 'Cherokee Brave' (CB). 


\section{Genomic analysis-DNA fingerprinting}

Using DNA amplification fingerprinting (DAF: Caetano-Anollés et al., 1991), 'Jean's Appalachian Snow', 'Karen's Appalachian Blush', and 'Kay's Appalachian Mist' were compared to one cultivar with red bracts ('Cherokee Brave') and four cultivars with white bracts ('Appalachian Spring', 'Springtime', 'Cloud 9', and 'Cherokee Princess'). Extraction, amplification, and electrophoresis of DNA, and data analysis were the same as those reported in Trigiano and Caetano-Anollés (1998).

The eight dogwood cultivars in the genetic analysis were heterogenous; $46 \%(108 / 235)$ of the character loci were polymorphic. Although similar, this level of heterogeneity was greater than another genetic study of flowering dogwood that used different cultivars (Windham et al., 1998). Unique markers were identified for each of the eight cultivars using the following $\left(5^{\prime}-3^{\prime}\right)$ octamer primers: GTTACGCC, CCTGTGAG, GATCGCAG, GTAACGCG, GACGTAGG, GAGCCTGT, GTATCGCC, CGTGGTGG, CCGAGCTG, and CCTGGTGG. DNA profiles using these primers were consistent and reproducible between three replications. Two, three, and five distinctive markers were identified for 'Jean's Appalachian Snow', 'Kay's Appalachian Blush', and 'Karen's Appalachian Blush', respectively. The genetic distances between all cultivars included in the study varied from $14 \%$ and $30 \%$, indicating a relatively heterogeneous genome (Table 2 ). Principal Coordinate Analysis of the data generated by DAF using NT-SYS version 2.0 (Exter Software, Setauket, N.Y.) readily distinguished all cultivars (Fig. 2).

\section{Availability}

Plant patents for 'Jean's Appalachian Snow' (PP 13,099), 'Karen's Appalachian Blush' (PP 13,165), and 'Kay's Appalachian Mist' (PP 13,098 ) have been granted. A limited quantity of bud sticks has been distributed to selected wholesale production nurseries in Tennessee. For a list of wholesale nurseries that have obtained budwood, contact R.N.T.

\section{Literature Cited}

Burrill, T.J. and F.S. Earle. 1887. Article VI. Parasitic fungi of Illinois, p. 387-428. Bul. Illinois State Lab. Natl. History. Part II. Vol. II. J.W. Franks and Sons, Peroria, Ill.

Caetano-Anollés, G., B.J. Bassam, and P.M. Gresshoff. 1991. DNA amplification fingerprinting using very short arbitrary primers. Bio/Technology 9:553-557.

Farr, D.F., G.F. Bills, G.P.Chamuris, and A.Y. Rossman. 1989. Fungi on plants and plant products in the United States. APS Press, St. Paul, Minn.

Hagan, A.K., G.J. Keever, C.H. Gilliam, J.D. Williams, and G. Creech. 1998. Susceptibility of cultivars of several dogwood taxa to powdery mildew and spot anthracnose. J. Environ. Hort. 16:147-151

Klein,L.A.,M.T. Windham, and R.N. Trigiano. 1998. Natural occurrence of Microsphaerapulchra and Phyllactinia guttata on two Cornus species. Plant Dis. 82:383-385.

McRitchie, J.J. 1994. Powdery mildew of flowering dogwood. Plant Pathol. Circ. No. 368., Gainesville, Fla.

Ranney, T.G., L.F. Grand, and J.L. Knighten. 1994. Resistance of Cornus kousa taxa to dogwood anthracnose and powdery mildew. Proc. Southern Nurserymen's Res. Conf. 39:212-216.

Royal Horticulture Society. 1990. Royal Horticulture Society Colour Chart. Royal Hort. Soc. London.

Santamour,F.S., Jr., and A.J. McArdle. 1985. Cultivar checklist of the large bracted dogwoods Cornus florida, C. kousa and C. nuttallii. J. Arboricult. 11:29-36.

Trigiano, R.N. and G. Caetano-Anollés. 1998. Laboratory exercises on DNA amplification for evaluating the molecular diversity of horticultural species. HortTechnology 8:413-423.

Windham, M.T. 1996. Resistance to powdery mildew in flowering dogwood. Proc. Southern Nurserymen's Assoc. Res. Conf. 41:197-199.

Windham, M.T. and W.T. Witte. 1998. Naturally occurring resistance to powdery mildew in seedlings of Cornus florida. J. Environ. Hort. 16:173-175.

Windham, M.T., E.T. Graham, W.T. Witte. J.L. Knighten, and R.N. Trigiano. 1998. Cornus florida 'Appalachian Spring': A white flowering dogwood resistant to dogwood anthracnose. HortScience 33:1265-1267. 